\title{
Ideology of Exile and Problematic of Globalization in Al Baraduni's Poetry
}

\author{
Rashad Mohammed Moqbel Al Areqi \\ English department, Sana'a Community College, Sana'a, Yemen \\ \& \\ Faculty of Sciences and Arts, Al Mandaq, Al Baha University, Saudi Arabia \\ E-mail: alarikirashad@yahoo.com
}

Received: 07-11-2015

Published: 01-05-2016
Accepted: 27-01-2016

doi:10.7575/aiac.ijalel.v.5n.3p.16
Advance Access Published: March 2016

URL: http://dx.doi.org/10.7575/aiac.ijalel.v.5n.3p.16

\begin{abstract}
Exile and Globalization are two postcolonial terms that reflect the reality of the communities and the influence of such terms on the lives of the people inside or outside their communities. Exile and globalization have gained special concern in the poetry of Abdullah Al Baraduni, a Yemeni poet. The article traces the influence of such terms upon the lives of Yemenis through two selected poems of Al Baraduni. Both terms would lead one of them to the other; in exile, the person would be distanced from his culture, language, tradition, religion and separated from his community, as a result, the person will be permeated by the global cultures that do not recognize any cultural or social restrictions on the other aspects of lives. Al Baraduni reflects a live picture of the Yemeni community in particular and the Arab community in general and how the person feels exiled in his/her country. Globalization makes the international communities get smaller and establishes many crossroads in their daily lives. Through these two postcolonial terms and through two poems of Al Baraduni, the article addresses these two concepts in Al Baraduni's poetry and how he depicts their influence upon the community in very attractive image, using brilliantly metaphorical images and interesting expressions that make exile and globalization as unavoidable terms in the lives of Arab people. Al Baraduni explicates the influence of exile and globalization upon the Yemeni lives in particular and the Arab world in general. It is inescapable influence reflected in all aspects of daily lives.
\end{abstract}

Keywords: exile, ideology, globalization, postcolonial, Al Baraduni, Yemeni, problematic, poetry

\section{Introduction}

Late Al Baraduni is one of the pioneers in the area of literature, particularly poetry in Yemen and in the Arab world in general. He is open and considers one of the advocates of women rights in the era of democracy that led him to receive death threats from religious fanatics who considered him an infidel. Abdallah Al Baraduni was born in Baradun, 1929 in Dhamar, northern part of Yemen. At very early age, Al Baraduni got blind after contracting small pox. This incident would not halt his aspiration to be something in his community. At early of his age, he joined the Grand Mosque and later moved to Dar Ulum in 1940 to study literature. He studied Arabic literature and Shari 'a to obtain a degree in this area of interest. He graduated from Dar Ulum with distinction in the area of Shari' a and Arabic language. He initiated his academic and professional life as a teacher of Arabic literature in Dar Ulum which led him to address many political issues in his poems that caused him problematic with the countrymen. For such reasons, he was imprisoned in different periods of the three decades $(1950,60 \mathrm{~s}$, and $70 \mathrm{~s})$.

His talent in poetry appeared early when he was thirteen years old. He began to read the classical poems of the great poets in the past and he attempted to write his own poems. He has written many books and articles that address many literary and political issues; however, his passion to poetry leads him to give priority and special concern to poetry which goes beyond the Yemeni borders to encompass the regional and international interests. He has published six books on literature, culture and politics, in such books he makes the picture clear about a man who bears a concern of a nation. Al Baraduni has published a host of studies, including Yemeni Issues, A Journey in Modern and Ancient Yemen Poetry, Popular Culture, Yemeni Experience and Sayings, Popular Culture in Yemen, From First Poem to the last Bullet: A Poetic Study of Zubairi's Poetry and His Life, and Culture and the Yemeni Revolution.

He has published twelve volumes of poetry which address his experiences and beliefs in social and political life and reflect the reality of political and social life of Yemeni and Arab communities. He has published On The Path of Dawn, From the land of Sheba, The City of Tomorrow, Journey to The Green Days, Smokey Faces in Night Mirrors, The Quality of Time, Creatures of Second Nostalgia, The Return of Wiseman, Bin Zaid, Answer to the Ages...etc. Al Baraduni lived very simple life and he wrote about what he believed in transparently. After 1962 revolution, he worked in Sana'a Broadcasting Radio to be a manger in 1969 and then the head of the programs department to 1980 . He was in charge of presenting a literature program called' Magazine of Thought and Literature'. He continued in this program to 
his death in 1999. Further, he supervised the Army Magazine from 1969 until 1975 and he had a weekly article 'Thought and Literature Issues', he wrote another weekly article for Al Thawra Newspaper entitled 'Cultural Issues'.

The focus and the issues discussed in Al Baraduni's poems do not exceed the concern of the Yemeni and the Arab citizens who long to an honorable life and he explains such issues in his poems and the political corruption which hinders the progress of Yemeni people to catch up with the civilization. He criticized the Imamates in some of his poems which have been circulated secretly in 1948; however, such poems led him to spend nine months in the prisons of Imamate governors. He was interested in women's issues in his poetry and his daily life; he worked for two years, 1954-1956 as a lawyer of women. He got benefit from his information in the area of Sharia which was a part of his study to defend the issues and the rights of divorced women to be known later as 'divorcees' lawyer'.

Al Baraduni is one of the greatest poets in Arab world and he is known more in Yemen in particular. He managed to write what the sighted people could not see; this deep insight engraved a name for Al Baraduni in the world of Arabic literature. He was able to combine between classicism and modernism between Ancient and contemporary in his poems. His special techniques and style add special flavor to his poems, specially the images and the simplicity of the language that reflect the reality of Yemen and the Arab world. He depicts the daily lives of the people and the routines they may go through in their country. His small nation, Yemen, and big world of Arab people catch his attention to write about the social and cultural issues, sacrifices and the sufferings to reach an honorable life under corruption of the rulers or exile and globalization enforced them to live different lives that are not matched with their simple dreams and their optimistic look to the future. Al Baraduni'e's literary writings, whether in the area of poetry or culture or literature in general, provide the readers with a profound insight and deep analysis into the realities of Yemenis and the Arab life in general, portraying the virtue and the vice, the triumphs and the defeats, aspirations and frustrations, sufferings and sacrifices. However, corruption in the community, the waves of globalization and exile that make the Yemeni lives a strange life that is not matched with his culture and social conventions. For this reason, such issues have been given a priority in his poems and literary writings. New aspects of invasion are dominating on the human life and they are practiced by the Arab people consciously or unconsciously. All aspects of human life are influenced in one way or another with the tides of globalization and the exile that are dominating on a great segment of Arab people. The language, the technique, the style, literary expression, symbolism, irony, and touching image are combined together to make the picture a live in the reader's mind.

Irony and satire in Al Baraduni's poetry have occupied a large space and they are employed to serve the criticism of social, cultural, and political reality. He has selected an ironic title for many of his poems, including: Vacuum Pioneer, Behind the Wind, Astonishing the Astonishment, We: Our Enemy, A Song of Wood, Sana'a in A Plane, Struggler in The Bed, Lightening Hunter, Winds Friend, Bad Advice, From Exile to Exile, Invasion from Inside...etc. Such titles mock the miserable reality which the Arab people live in and find themselves in a situation they would not able to change or goes beyond its circle.

The article addresses two poems of Al Baraduni: From Exile to Exile and Invasion from Inside. These two poems will be analyzed to recognize to what extent the poet succeed to depict the two postcolonial concepts and what are the techniques used to make the picture closer to the mind of the readers, using very simple language and alive images to make the readers understand the message behind such poems.

\section{Al Baraduni in the Eyes of Critics and Intellectuals}

Abdel Aziz Al Maqaleh pointed out "the great poet Abdullah Al Baraduni's passing away has left a great void in the area of poetry, the void can be filled only by his works, which were and will remain the subject of unlimited interest of the coming generation in Yemen". The ex-minister of Culture Mohammed Abu Bakr Al Maflahi stated "Al Baraduni is one of the most important symbols of global culture in the second half of $20^{\text {th }}$ century. He is one of those who raised the name of Yemen in the Arab and international forum. Yemen now has a prominent location on the map of Arab culture". He continued to confirm" Al Baraduni took upon himself to upgrade, develop, and renovate Arab poetry to become one of the best known poets" (Saba News Agency, 1999).

Al Baraduni has his own unique style and technique in painting the poetic images. He was a literary school by himself. Ali Aqla (2010) pointed out "Al Baraduni was a man of a nation, not a man of himself, he felt the people and he was not flattering or praising any one for his own interest. He hates humiliation of his nation...; he calls for dignity, freedom, courage, and struggle, declaring in such words the genuine sense of life" (qtd. Al Salum's Poets under the Light). Waleed Mushwah (2000) argued in his book 'The Poetic Image in Al Baraduni's Poetry' "Al Baraduni considers a modernist and a renovator in the context of classic school, he is creative and establish everything innovatively so that he deserved to be predecessor of Emru' Al Qais, the deluding king". The poems and poetry of Al Baraduni stimulate many critics and scholars to write about his unique literary school and his satiric approach in most of his poems. Al Baraduni has very supreme position in the hearts of millions of Yemenis and his efforts and deduction to his fair issues have engraved a name for him in the area of poetry and the area of literature in general. The critic Fawaz Haju (2010) discussed al Baraduni's distinction in his words and his images "Al Baraduni has his own voice and his own color, his poem are distinctive with symmetric music known for his lovers, and known by his voice layers. He does not belong to any literary school, he owns his own project"(qtd. Al Salum's Poets under the Light).

Al Maqaleh (2003) in his article "The Big Poet is Creative to the End", Al Thawra Cultural Attachment, called the scholars to address Al Baraduni's poetry in their master and PhD researches to go deeply to the beautiful expressions, the images, the senses and to argue "examples of Al Baraduni's poems, particularly, the late ones that have taken an 
artistic and human dimensions, more aspiring to represent the poetry in its modern style, and sometimes the postmodern ones" (4). Muhyi Aldin Saeed (2003), in his article " Al Baraduni is cheaper than Sawti" (Sawti is the worst and cheapest types of Qat-green leaves- are chewed by Yemenis) argues that " the truth should be confessed, we have lost Al Baraduni in our life, we have lost him a giant, a human, a poet, a critic, an artistic rebellion of the first type, but from a type could not be found yet" (6). In this article, Muhyi Aldin mentioned that Al Qa'ud addressed Al Baraduni that his books are available anywhere and they are cheap, the late Al Baraduni replies "they are cheaper than Sawti"

In Al Baraduni's fourth death memory, Abaid (2003), Al Thawra Cultural Attachment, pointed out that "the literary works of Al Baraduni followed one another which have immortalized his name as one of the poets who enrich the Arabic poetry and enrich Arabic literature with his distinctive and creative literary works. Al Baraduni is one of the modernists of the column poem and he is the most brilliant poet in the second half of twentieth century" (3). Al Baraduni participated from 11-15 December 1971 in celebrating the millennium memory of Abu Tammam, held in Mosel, Iraq, and he obtained the festival's prize for his famous poem "Abu Tammam and Arabism of Today". On 30 August, 1999, came to put an end to the big poet of Yemen, as he was called by Al Maqaleh.

\section{Exile and Globalization in Postcolonialism}

Ashcroft and et al (2002) pointed out "the condition of exile involves the idea of a separation and distancing from either a literal motherland or from a cultural and ethnic origin" (P. 92). Al Barduno has his own view and understanding to the concept of exile which is expressed in many of his poems and how the person would be exiled in his home and he is attempting to escape from such exile to another one. He could not feel that security he supposed to feel in his motherland. The citizen of the Arab country may find himself/herself a stranger among his/her people and his/her culture.

Regarding globalization, Ashcroft and et al (2002) argued "globalization is the process whereby individual lives and local communities are affected by economic and cultural forces that operate world wide" (P.110). The idea of globalization comes as a substitute of the imperialism which practices its domination through the military forces. The metropolitan power of western countries envelope their influence on the other culture and economy by brilliant name that make the Arab world and the other helpless countries drift with their intellectual and cultural invasion. At the beginning such powerless countries called such interference in their culture and community a sort of intellectual invasion, however, the imperialist power and the dominating forces initiate in marking such interference with brilliant names such as globalization, secularization and hegemonization. Consequently, the Arab people become followers and implementers to such ideologies which lead them far away of their language, culture and religion in the name of modernism or in the name of coping with the tide of civilization.

Imperialists make it easy to themselves by propagating to such ideologies that shift the reality of the Arab people through such lovely names. Many of Arab people have embraced such ideologies, but they begin to call to such ideologies in the name of openness to the global world as a response to the requirements of development and the fast growing changes in the world. A huge change has occurred to the powerless communities and they may not be able to protect themselves from such globalization problematic. The communities that own the power, they are the communities that make the change for their interest, but sometime they impose such change on the powerless communities. As a result, the transformation in the lives of the local communities drives them far away of their language, culture, religion and social traditions, they are drifted with the tide of the dominating power that controls the economy and the technology of the contemporary era.

\section{Exile as an Ideology: From Exile to Exile}

Al Baraduni is one of the greatest contemporary Arab poets who are distinguished by his style and his techniques that make the critics put him as a literary school by itself. The political, cultural and social situations that get the country to the worse make Al Baraduni's poems blended with the tone of irony in most of his poems, if not all. The title of the poem is selected creatively. The reader may touch the ironic and satiric tone even from the titles of most of his poems and collections that reflect the suffering and struggling of the people and the corruption of Arab nations which has taken varied aspects. In the selected poems, this article focuses on the reality of globalization problematic and the ideology of exile in Al Baraduni's poems. From exile to Exile is one of the poems that will be analyzed and highlighted to probe deeply into the poet's projection and views of such postcolonial terms which they have taken a new trend to be spread and practiced with excessive passion.

Al Baraduni's poems express the concern of Arabs in general and the concern of Yemenis in particular. His dignity and love for his country, his codes and ethical criteria make the poet stands against the corruption which is embodied in the Arab Rulers and their practicing corruption and exile against their citizens. He struggles with the power of words and the power of poems which makes him one of the great nationalists who endeavors everlastingly to uncover the lies and tricks of the rulers who become a tool of globalization and world imperialism. His poems come to express the pains and the promises of the people of his country. He feels as the others who live the life of exile even in their country which is supposed to be a safe refuge for them. The exile ideology and globalization problematic become a hidden weapon that are used against the people whose dreams to live normal lives away of cultural loss and identity problematic. The interest of the Arab rulers meet with the ideologies of exile and globalization which push the indigenous people to be driven towards the tenets of globalization which have given it a likable name, instead of thought invasion. Globalization becomes a necessity in the eyes of the rulers to make their people subservient to their orders. 
The poem of From Exile to Exile comes to express the passion of the rulers to hand over their country from a tyrant to another one. It comes to stress the transformation of the people identity under the tenets of globalization that cross the cultural and social limits. Globalization and exile become inescapable destiny of the indigenous people.

\section{From Exile to Exile}

My country is handed over from a tyrant to the next, A worse tyrant, from one prison to another,

From one exile to another.

It is colonized by the observed

Invader and the hidden one;

Handed over by one beast to two

Like an emaciated camel.

Al Baraduni's words come honest and powerful and his pain as one of the people of this country is unquestionable. It belongs to him, and his love to his country makes him suffering. The irony that may see in the title, it would depict the country situation, the country that supposes to be a safe refuge to the citizens, suddenly it becomes as an exile, and this exile leads the person to another exile. The name is my country only but it is completely different. The tyrant rulers are determined to hand over the country to the worse rulers whose concern is nothing about the suffering of the people. It is a matter of a country which lives under corruption and undeclared exile. The country pre-revolution and post-revolution era is suffering the dominations of the tyrant rulers who see nothing but only their self interests and such interest only meet with the global imperialism.

In the past, the invaders were known and would be observed, now the invaders are hidden and are revealed under brilliant names as globalization, secularization, hybridization...etc. such hidden ideologies that make the people follow and feel themselves lost. The poet portrays the everlasting changes under the impact of globalization and exile as inescapable transformations. To be under globalization power, no limits would be touched. The world becomes small village shares global culture, global conventions, and global politics. The indigenous people in Arab country feel exiled. Every one of such postcolonial terms: exile and globalization, lead one of them to the other, having influenced by exile, you find yourself permeated by the global culture and having globalized you would feel exile and alienation.

The irony is that the anticipated change could not be fulfilled and the country situation controlled by tyrant ruler and handed over to another tyrant. Here the reader may realize the pessimistic attitude of the poet and how his country dominated by one tyrant to be handed over to a worse one, from prison to another, from exile to another, from one beast to two, from observed invader to hidden. The people as they have no power to resist the tyranny. The hope of the poet is weak in changing the situation as long as the tyrants handed the rule to the worse tyrant. The poet compares between two eras: pre-revolution and post-revolution, between past and present. The revolution is supposed to bring honorable life for the citizens; however, the poet finds the situation get darker and worse. The hopes and dreams of the citizens do not come true and promises of prosperous life are vanished under the corruption and tyranny of the rulers.

The hidden invaders are represented by the globalization and its policies carried out by the Arab countries rulers. The rulers become the tool in the hands of international imperialism that endeavors to change the identity of the locals to let them feel lost and torn between such global cultures, religions, and social conventions. The country, the poet means Yemen, is controlled by indirect western globalization. The cultures and values would be dissolved under the tenet of globalization and the ideology of exile, even in the country which the person lives in. The present policy is a nation believes in globalization as an unavoidable refuge and such globalization is practiced by hidden invaders as the poet called them. The poet's country still live in the caverns of its death, and it searches for the pure origins that have been lost by exile and globalization ideologies.

$$
\begin{aligned}
& \text { In the caverns of its death } \\
& \text { My country neither dies } \\
& \text { Nor recover. It digs } \\
& \text { In the muted graves looking } \\
& \text { For its springtime promise, } \\
& \text { That slept behind its eyes. } \\
& \text { For the dream that will come } \\
& \text { For the phantom that hid. } \\
& \text { It moves from one overwhelming } \\
& \text { Night to a darker one. }
\end{aligned}
$$

The words used are expressive and explain the pains of the poet: caverns- death- dies-dig-graves-night, a darker night. Such words move the readers to a scary world and the position of in- between: no genuine life with real sense and no real recovery that brings hope to the people. The ray of hope is far-fetched which are expressed by the interesting 
expressions such as dig in the muted graves looking for its springtime promise/slept behind its eyes/ the dream that will come/ for the phantom that hid/ from overwhelming to a darker one.

My country grieves

In its own boundaries

And in other people land

And even in its own soil

Suffers from the alienation of exile.

The poet used "my country" to express Yemen in all aspects of life: Yemen in its human and history, Yemen in its culture and identity, Yemen of people and place. Yemen becomes an exile and the ideology of exile and globalization are enforced by the leaders who become a hidden tool of change and a tool of devastation. For this reason, the poet depicts his country sad behind its boundaries and the people of Yemen live miserable life in their country and in the other people's land. Grief and suffer become a mark of exile and alienation. The people are drifted by globalization that makes them strangers and exiled in their country. They find the culture, the faith, the social conventions are not what they recognize and the life is different. Such life does not belong to their history or to their heritage. The second poem which the article argued to be familiar with the sort of life led by the leaders and the poet's country rulers is a poem entitled 'Invasion from Inside'.

\section{Invasion from Inside}

It is terrible the ignorance of what is going on

And more terrible to recognize

Do you know Sana'a who the secret colonizer is!

Invaders who are not observed and their invading sword in my chest

They would come in tobacco of the cigarette, its color tempting

In charities of a beast humanizes its rocky face

In the eyelashes of a female, in dominating fancy tissues

In a teacher's trousers, and under the head cover of the religious reciter

In the anti pregnancy tablets, in tube of ink

In the freedom of vomiting, in the absurdity of the age

In the return of the past colonization, in its modern disguise

In the bottle of whiskey, in the bottle of perfume

They are hidden under my skin, and get out of my hair

And above their faces my face, and under their horses my back

Invaders of today are like plague, hidden but it spreads

Hold the birth of the coming and embroider the miserable presence

It is terrible the ignorance of what is going on

And more terrible to recognize.

The late Al Baraduni had a profound insight into the political and social situations in Yemen. His words have been seen a reality in the history of Yemen, whether in the past, during his life or in the future of Yemen after his death. His words have touched the sufferings and aspirations of Yemenis and the Arab people. His expectations about the future of Yemen are unmissed because they come from the heart that recognizes no hypocrisy or flattery to the politicians or rulers of Yemen. What Al Baraduni wrote in the past is reflected in the reality of political arena of Yemen. Most of the titles of Al Baraduni's poems satirize the political and social situations; they are full of exciting and mocking expressions that the poet may not be able to change. The poem which will be analyzed here is 'Invasion from Inside', his mockery overturns the understanding of human beings to the reality and the ordinary use of the words, his words lead the reader to think many times to realize what the poet aims at or like to criticize in his poem. The inferences in his poems may be realized by distinctive expressions and wonderful images. The use of the words and the simile in his own way that give the readers a remark that everything is overturned, even the reality and aspiration of the nation we suppose to see or the leaders suppose to work on alleviating the pains of the nations, on the contrary, they work in one way or another in devastating the values and culture of their nations. In the title of the poem, the reader expects the invasion from outside however, to find invasion from inside and the leaders of the Arab people become a part of this destruction, here the poet mocks Arab countries subservience to the foreign ideologies, particularly, Yemen. It becomes a mark of globalization and exile. The people are not the people, the person may see the past is not the past and the values become hybrid and globalized. What the western countries call for, you may find its reflection in the Arab world in the second day because of the power of technology. Ashcroft and et el (2002) argued that "the most active area of 
debate in globalization studies therefore appears to be the style and the nature of the process by which external and internal forces interact to produce, reproduce and disseminate global culture within local communities" (114). Ashcroft and et al emphasized that "the more recent directions of globalization studies concern the development of global culture, a process in which the strategies, techniques, assumptions and interactions of cultural representation become increasingly widespread and homogeneous" (114).

Al Baraduni begins his poem 'Invasion from Inside' with an astonishing cry that expresses his shock of what he realizes around him. /it is terrible what going on/ and more terrible to recognize/ to see something unexpected, and the more terrible to recognize and stand powerless to resist such undesirable transformation that makes the people deny their cultural and social values. The impact is huge and no one may imagine. The poet is confused of what he sees in Sana'a, the landmark of old civilization, something is run behind the curtains. The poet addresses Sana'a/ do you know Sana'a who the secret colonizer is! / It is painful to find Sana'a as a mother whose sons work secretly to respond to the conspiracies of the enemies, but they become the tool used by the external colonizers in very tempting names that reveal the matters go in the interest of the nations which export the technology and civilization. They come under the names of globalization, hybridization, secularization ...etc. that names which delude the locals to run behind such slogan which do not serve just the international imperialism.

Al Baraduni's poems are rich with different types of techniques that reveal irony, satire and sarcasm. The ironic question is one of these techniques which stimulate the reader to draw a live picture in his mind about the miserable political and social situations. Al Baraduni was raised in a poor family and in that small community, beginning with his family and loss of his mother at the early age. He was living in a community known with irony and sarcasm that dealt with the reality of the rulers' daily lives. Such life would enhance the poet's talent of irony. Further, his reading of the classical poems of the past poetry empowers his ironic and satiric techniques despite the differences in the political and social circumstances of the two ages. The poet sometimes uses the ironic question, other times would use repetition that call attention of the reader to the purpose of repetition as /it is terrible what is going on...etc/ in this poem. He uses the question techniques. The poet draws a caricaturist image that makes the reader laughs during reading the poem. Al Baraduni poems may not be free from likable and attractive hyperbolic expressions that are not detached from the reality of the political situation noticed when Al Baraduni addresses the manifestations of globalization and exile in the poem.

The poet shows the colonizer of today is not as the colonizer of yesterday. The colonizer of today is more effective and devastative. This sort of globalization is admitted by the people as an urgent need required by the development and progress in the different areas of life. The poet's deep insights about the reality of situation in Yemen at that time and his prophecy of the future do not miss. The poet was able to see and predict what the people with their eyes may not realize. The words of Al Baraduni come to touch the core of the political and social reality of Yemen. The rulers of Yemen and the Arab world become the device of transformation, a tool of colonization that intends to change the values of the Arab nations to worse. Undoubtedly, the fast collapse of Sana'a under the corrupt rulers who see only their own interests puts a big question mark on the hands that run and control the political situation. That makes the poet starts his poem /it is terrible what is going on/ here the reader may realize the bitter fact. It is not an innocent change that may drives the Yemeni lives to better. However, they are ideologies that may make the people lose their cultural and religious values under very tempting names of modernization or globalization. They may lose their faith and their capacity to change the situation to better. It is a deliberate plan to devastate all the components of the community. The Yemenis find themselves under the control of hidden hands that lead them to be exiled in their country, to be confused and lost before this sweeping tide of globalization.

The poet addresses his words to Sana'a, his beloved, which is unable to defend herself against the hidden hands of globalization, but destruction. /Do you know Sana'a who the secret colonizer is! / A question expects many answers, to call the attention of the readers, particular Yemenis, to what he is going to explain. A question is to stimulate the readers to the reality of situation in Sana'a. The poet asks and he brings the answer, /invaders who are not observed and their invading sword in my chest/ Al Baraduni realizes the risks that envelope the Yemenis, and the poet is one of those people. He uses 'not observed', but their impact is horrible, their invading sword in his chest. It is expressive metaphor that depicts the situation and the unbearable pains in his deep chest. It is unavoidable situation which leaves a huge influence inside his chest. The poet is a symbol of all Yemenis. The invasion works secretly to change the values and identity of the people. The pains of the people are the pains of the poet who shows his national spirit affected by the invading sword that leave its consequence in his heart.

The poet initiates explaining the manifestations of the colonizers which come in different aspects; the tool of colonizers is globalization which is reflected in many forms: it is realized in the tobacco of cigarette that has been exported to Yemenis in its tempting color. The poet likes to show that the means of colonization adopts different ways to control the Arab nations. It also comes through charities, donations, and economic assistance offered by a beast /attempting to humanize his rocky face/ here in such image the poet reveals the ugly face of the colonizer who attempts to humanize his rocky face and reveals his mercy over the Third World countries. He describes the colonizer as a monster or a beast that likes to show kindness and humanity to the Yemenis. The poet uncovers the genuine face of the donors. The invasion may come in the eyelashes of a female in her dominating fancy tissues. The person finds himself under the influence of such fancy. The invaders may come in a form of a teacher's trousers and the head's cover of a Holy Quran reciter. Here the poet argues how the invaders manages to reach the religious man's traditions and values by showing 
that their globalization means to invade even the religious figures to cover his head by a cover manufactured in the invaders' countries. The poet likes to show the readers to what extent the influence of globalization has reached.

The globalization becomes problematic and controls all aspects of Arab lives. Its resistance may not be easy because it becomes a part of their daily lives. The uniform of the Holy Quran reciter is a symbol of his commitment to his religion and tradition but globalization spoils the Yemeni heritage and traditions. The poet continues explicating the manifestations of the secret colonizer who prefers to make use of the indigenous rulers to carry out their policies and plans in their motherland, instead of face to face confrontation with the indigenous people, the colonizers make use the leaders of the nations to carry out their destructive policies. The invasion may come in a form of /anti- pregnancy tablets and tube of ink/ in the freedom of vomiting. /In the absurdity of the era/ the invaders may not hesitate to work by the hidden means in its modern disguise. The mockery is that the people become users to all the products of the invaders, how the readers expect such people may unfetter from the globalizing shackles. The invaders' means show themselves / in a bottle of whiskey, in a bottle of perfume/their means and modes may not be seen, they always hidden and are practiced by the locals unconsciously. The poet shows how the invaders' means dominate all aspects of life.

Al Barduni uses a very interesting image that uncovers the invaders' hidden techniques that the person may not pay attention to such means. This technique of hyperbole may reflect the ironic domination of the colonizer on the aspects of daily lives of the people. /they are hidden under my skin, and get out of my hair/and above their faces my face, and under their horses my back/. The aesthetic quality of such image makes the reader realizes how the people are influenced by the globalizing movement that settles under the skin of the people and the poet is a part of this community. The poet expresses the invaders' hidden hands as they are hidden under the poet's skin to portray how they work secretly and in darkness. It is very beautiful image that makes the people permeated with the globalizing culture and become the users of the products of the colonizers that control their lives, but they become the masters of globalization. The Arabs and Yemenis' leaders in particular become a source of globalization and become the exporters of such ideologies to their people. /get out of my hair/ and above their faces my face/ and under their horses my back/. The poet depicts how the locals' acts as they are the inventers of such ideologies that make the invaders themselves wear the faces of the poet as a symbol of Arab subjection to the western globalization. The Arabs' back is ridden by their horses and this image shows the reader how the Yemenis become perfect carriers to the globalizing manifestations in their lives, but they become a very significant incarnation of such globalization. It is very expressive and attractive picture that may clarify how the indigenous rules become the followers of the globalizing style of life. Al Baraduni in his unique skill makes the picture a live in our mind and it does not miss the element of irony.

The poet describes the invaders of today like / plague, hidden but it spreads/. The Yemenis require to hold the coming birth if they like to stop the influence of the invaders in their modern manifestations, or to decorate the miserable reality. Therefore, the influence of globalization is inescapable because the impossibility of halting the coming birth or decorating the miserable reality of Yemen. The poet repeats his clarion cry which is repeated at the end of the stanzas to portray the horrible reality of the situation in Yemen. /it is terrible the ignorance of what is going on. And more terrible to recognize/. It is a misery of a nation led by his rulers to obliterate the authentic identity of a nation which reflects the style of globalization. They live strange lives which are not involved with any of their cultural, social or political conventions. The poet points out in the following lines the reality of the Yemenis whereas in the first part of the poem the poet explicates the manifestations of globalization, the invasion in its modern disguise. The poet uses many symbols that reveal how the globalizing ideology comes to the people. It is manifested in tobacco of cigarette, charities of a beast, eyelashes of a female, a trousers of a teacher, a cover of reciter's head, anti- pregnancy tablets, tube of ink, in a bottle of whiskey, a bottle of perfume...etc., they become the controller of the lives of the people and penetrate into their lives deeply to become stuck under their skin and get out of their hair.

The poet depicts the people's subservience in a very humiliating way that makes them as the caller of globalization. /and above their faces my face/and under their horses my back/. It is very profound insight that explicates how the indigenous people of Yemen and Arabs in general become a tool of globalization. The poet emphasizes that is hard if not impossible to stop such invasion which moves secretly and spreads rapidly. The influence is horrible and unavoidable in a time of revolution of technology, what is invented in the west today, tomorrow it becomes in our country as an urgent need and the people may not ignore.

Yamniyoun are in exile, and others are exiled in Yemen

Southerners are in Sana'a, and northerners are in Aden

As uncles and relatives are in their determination and their weakness

October walks turn into September coffin

The shame is promoted from selling to priceless selling

And from an invading colonizer to a national one

Why we are, oh settling, oh exiling, houseless

Without dream, without mention, without condolence, without grief

Yamaniyoun, oh Arwa, oh, Saif bin Zee Yazen

But despite of you, we are without blessing, without Yemen

Without past, without future, without secret, without exposure 
Oh Sana'a, when do you come from your rotten coffin?

it asked me, do you know?! My time ends before it comes

When I come?!!Don't know to where my ships have bent

it came back from its future to its pagan history

It is terrible the ignorance of what is going on

And more terrible to recognize

The poet describes the political and the social situation, how the Yemenis become under the influence of such new ideologies which dominate every details of their lives. Yemenis become exiled outside of Yemen and exiled in their home. Yemenis live this sort of exiled lives, whether inside or outside. This is the reality of the situation. The poet claims everything is overturned. The people suppose to feel secure and live their identity in their home; however, they feel exiled even in their homes because the same power that leads them to feel exiled abroad, it is the same power that drives them to feel exiled in their home. /Southerners in Sana'a and northerners in Aden/ Sana'a is the capital of Yemen before unification the two parts of Yemen and the capital of Yemen after the unification of the two parts of Yemen. Aden was the capital of the Southern part of Yemen. They are like uncles and relatives in their power and their weakness. /October walks turn into September coffin/ here the poet elucidates how the revolution of the southern part of Yemen becomes the coffin of the revolution of Northern part of Yemen. The people leave their religious and social values behind and begin to feel exiled even in their home. Everything becomes overturned in their lives. The irony here is /the shame is promoted from selling to priceless selling/ and from an invading colonizer to a national one/. The problem that alligators of nationalism become the sellers of western ideology of globalization to their nations, instead of the external colonizers, the national one appears on the surface. The people are suffering whether in their settling or exiling: houseless, without dream, without mention, without condolence, without grief. The poet is crying on the blessing the people lost and the people are homeless that may protect their past, present, or their future.

In the above part of the poem, the poet tells us how the people under such ideologies behave. The poet complains to the historical symbols of Yemen. Globalization invades every part of their daily lives. /Yamaniyoun, oh Arwa, oh, Saif Bin Zee Yazen/. The dialogue with the historical symbols and using symbolism of the past are a tool of Sarcasm and irony that alleviate the pains and the bitterness of the miserable reality. He addresses the symbols of the past who ruled Yemen for a period of time. Yemenis become despite those historical symbols in the history of Yemen, without blessing without place, without past, without future, without secret, without exposure. They have lost their wonderful history and their own identity. The situation is terrible. The poet addresses Sana'a, his beloved, /oh Sana'a, when do you come from your rotten coffin/. it asked me, do you know? My time ends before it comes/. The poet wonders when Sana'a comes from its rotten coffin; Sana'a may not have sufficient time to celebrate its new birth after 26 September revolution. The new rulers do not give her a time to enjoy this moment. Therefore, Sana' declares that her time ends before it comes. This personification is interesting and reveals Sana'a as powerless girl unable to celebrate her new birth day. When it comes after the revolution, she does not recognize to where her ships bent. Instead of moving to a brilliant future, her future returns back to the pagan history. It is terrible the ignorance of what is going on and more terrible to recognize and stand hopeless and helpless.

My motto today, oh master, we are the plant of your fertilization

Because your richness makes us kneel at the feet of your lovers

We make you a God: and the sun is a ray of your origins

Oh, sleep Babik Al Kharmi, on Balqees, oh Babik

Her ringlet of hair a bed of your fancy, some of your masters' fading

And in the name of the God, Al Mighty, drink the glass of your toast

The prince of oil, we are your hands, we are your sharpest canines

We are the thirsty leaders to the remains of your cups

And officials in Sana'a, and servants at your door

From our blood over our blood locating the army of your terrorism

We have come, pulling the people to the first steps of your gate

And we do what you like, clean up the shoes of your guards

And beg you titles that are culminated with your titles

Command us as your intentions of the den night likes

We beg you titles culminated your titles

Yes, the master of tails, we are the best of your tails

It is terrible the ignorance of what is going on

And more terrible to recognize 
In the above mentioned lines, the poet moves to explain to where the rulers lead their nation. /my motto, oh master, we are the plant of your fertilization/ because your richness makes us kneel at the feet of your lovers/. Here the poet casts the blame on the people who work on increasing the power, the money of the rulers and this sort of their richness leads the nation to be slaves at the feet of the leaders' lovers. The people exaggerate in their esteem to such leaders, they make them a God and the rays of the sun are a sign of his origin and power. The Poet still conjures up his memories about the past, the poet would not bear the recent situation which is realized in the daily life of Yemenis. He mocks the situation and calls the symbols of absurdity and illegal enjoyment of the past to sleep on Balqees that strong woman who rules Yemen in the era of Suleiman, the prophet and later she has married him. Babik Al Kharmi is one of the callers who stood against Al Abbasid state in the past and he propagates for false faith that is not involved with the true God. He uses this sort of contradiction to show the absurdity of the time. How the evil would prevail the good. This is the irony of the fate. He calls for illegal enjoyment and the word of 'khurm' is a Persian word that means illegal enjoyment. The critics blame the poet how to use that symbol of Balqees to explicate how the matters are overturned in Yemen. The poet likes to show to what extent the absurdity and anarchism reach in his country, Yemen. It is a sort of accepted exaggeration or hyperbole to lead the reader thinks to where the national invaders lead their nations to. Babik Al kharmi is a symbol of corruption in the past becomes absurdity symbol of the recent leaders, to enjoy the ringlets of Baqees hair and they have to drink the toast of celebration. It is inappropriate matching because at the end Balqees believes in real God and has married a prophet, whereas Babik Al Kharmi continued in his false faith and endeavored to satisfy his sensual pleasures. This is a mocking remark that portrays how everything gets reversed.

Al Baraduni moves to the regional situation. At the beginning he addresses globalization and its manifestations in the daily lives of Yemenis, and then he drags attention of the reader to the historical symbols of Yemen such as Arwa, Saif Bin Zee Yazen, and Balqees. He compares the past symbols to the present rulers and how the big difference is between the past symbols and the today ones. The poet depicts how the leaders of Yemen recently become beggars at the gates of the princes of oils. / The prince of oil, we are your hands, we are your sharpest canines/ we are the thirsty leaders to the remains of your cups/ despite such humiliation and obedience to the prince of oil, what the leaders get is the remains of the cups. This is a sign of very simple thing what they get from the masters of oil. The leaders and officials of Sana'a become servants at the door of the oil princes. The poet depicts the humiliation of the officials of Sana'a reach to get simple donations from the masters of oils. The poet expresses how the leaders carry out the commands of the princes of the oil to terrify their people/ from our blood over our blood.../ here to show you how the officials of Sana'a provide the precious thing to respond to the masters of oil by terrifying their people. The expression used by the poet is to clarify /from our blood over our blood/ the officials exert efforts to satisfy the demands of the oil masters and these efforts to horrify their people who are connected with them in blood.

It is very humiliating to find the leaders of Sana'a, /pulling the people to the first steps of your gate/ they carry what the master of oil like even if it reaches the cleanup of guards' shoes of their masters. Al Baraduni with his ironic, satiric images and words managed to depict the extent of humiliation the officials of Sana'a reach and he embodies the core of globalization that is based on responding to the demands of the masters of power and oil from the east or the west. They bestow official with titles to satisfy their arrogance. /command us as your intentions of the den night likes/ the official receive their orders from their masters and request titles culminated their masters' titles. The leaders of Sana'a act as a tail to the princes of oil. This image explicates to what extent the leaders become subservient to the masters of oils and to what extent they become followers to their masters. The political and social situation is miserable in Yemen. The poet ends his lines with the same lines he uses at the end of each part of the poem / It is terrible the ignorance of what is going on/ And more terrible to recognize. This end is to catch the reader attention to the bitterness and the misery of political situation in Yemen, whether pre-revolution or post revolution. The Arabic poem has its aesthetic quality that the English translation version could not reveal appropriately.

\section{Conclusion}

Al Baraduni addresses in the selected poems the influence of globalization and its manifestations that cause problematic and confusion in the identity of the Yemenis. Exile ideology makes Yemenis subservient to its consequences and they live the life of exile inside/outside their country. Globalization and exile ideologies invade all aspects of Yemeni lives and their influence is unavoidable. Every one of the two terms argued in the two selected poems of Al Baraduni affect the other, feelings exile because of the globalized life that leads the Yemeni away of their culture and social and religious values, simultaneously, exile may be felt even in their home because everything becomes bizarre and the people find themselves detached from their identity and their culture.

Al Baraduni argues in the two selected poems the manifestations of exile and globalization that lead the lives of Yemeni to the worst. The rulers and the officials of Sana'a, as the poet claimed, become more stuck to such terms of exile and globalization and they lead their country to worse and to loss. The rulers are eager to carry the western policies of globalization and exile more than the makers of such policies. The poet uses many ironic/satiric images that make the picture alive in the minds of the reader and how the officials of the Arab countries turn into beggars at the gate of the masters of oil, wealth and respond instantly to their orders which lead their nations to such humiliating position. Al Baraduni portrays how the leaders of his country drive their people to be servants for their masters. Al Barduni in the first poem depicts how the rulers of Yemen give the throne to the tyrants who are worse than them and lead the country from a prison to another, from a tyrant to worse, from a beast to two, from exile to another exile, from an invader to a hidden one. Exile and globalization become in Yemen two faces for the same coin, no one may escape from their 
negative influence that lead the people to lack their identity and live in between lives that dominate the authenticity of their principles and values.

The article showed how globalization and exile leave its deep influence upon the Yemenis' aspects of life. The manifestations are seen in all commodities produced by the westerners. Sana'a officials become servants for the masters of oil. The poet pointed out how life become hard for Yemenis whether inside or outside of Yemen, the people are suffering exile and globalization even in their home. The indigenous people leaders represent the national/internal invasion, but the tools of globalization and exile. The community of Yemen feels the problematic of globalization and the inescapable exile. The problem is that the leaders of Yemen who hand over the country from a tyrant to worse and they become more excited about such postcolonial terms of globalization and exile. They work only to secure their self interests.

\section{References}

Al Maqaleh, A. (2003). The Big Poet Creative to the End. Al Thawara Newspaper, Cultural Attachment, 1September, no. 14173 .

Al Maqaleh, A. (2015). Modern Remarks in Al Baraduni's Poetry. 26 September Newspaper, no. 1082, p. 6.

Al Maflahi, Ab. (2000). Saba News Agency.

Al Mushah, W. (2000). The Poetic Image in Al Baraduni's poetry. Al Riyadh Book. Al Yamamah Foundation.

Al Mushah, W. (1995). The Irony in Al Baraduni's Poetry. Union of Arab Writers, Damascus.

Ashcroft, Bill. Griffiths, Gareth and Tiffin Helen. (2002). Post - Colonial Studies. Routledge: London and New York.

Jaber, A. (1992). The Artistic Image in Critical and Rhetorical Legacy of Arabs. Arabic Cultural Center. Beirut.

Musa'd. A.D. (2010). The Irony in Abdullah Al Baraduni's poetry. Umm Al Qura University.

Obaid, M. (2003). The Teacher died. Al Thawar Newspaper. Cultural Attachment. 25 August, no. 14166.

Saeed, M. (2003). Al Baraduni is Cheaper than Sawty. Al Thawra Newspaper, Cultural Attachment, 1 September, no. 14173. 